\title{
TOURISM INDUSTRY DEVELOPMENT AND GOVERNANCE: A COMPARATIVE STAGE REVIEW OF KAZAKHSTAN'S EXPERIENCE FOR THE YEARS OF INDEPENDENCE, 1991-2020
}

\author{
Bakhyt AKTYMBAYEVA \\ Narxoz University, School of Economics \& Management, 050035, Zhandosova st., 55 Almaty, Kazakhstan; Al-Farabi Kazakh National \\ University, Faculty of Geography \& Environmental Sciences, 050040, Al-Farabi ave., 71, Almaty, Kazakhstan, e-mail: B.Aktymbayeva@ narxoz.kz
}

Umyt KOSHKIMBAYEVA*

Al-Farabi Kazakh National University, Faculty of Geography \& Environmental Sciences, 050040, Al-Farabi ave., 71, Almaty, Kazakhstan, e-mail: Koshkimbayeva@kaznu.kz

\section{Zarema ABISHEVA}

Al-Farabi Kazakh National University, Faculty of Geography \& Environmental Sciences, 050040, Al-Farabi ave., 71, Almaty, Kazakhstan, e-mail: Abisheva@kaznu.kz

\section{Ulzhalgas TOKBERGENOVA}

Almaty Technological University, School of Economics \& Business, 050000, Tole Bi st., 100 Almaty, Kazakhstan; Al-Farabi Kazakh National University, Faculty of Geography \& Environmental Sciences, 050040, Al-Farabi ave., 71, Almaty, Kazakhstan, e-mail: Tokbergenova@atu.kz

\section{Markhaba TUMAZHANOVA}

Almaty Technological University, School of Economics \& Business, 050000, Tole Bi st., 100 Almaty, Kazakhstan; Al-Farabi Kazakh National University, Faculty of Geography \& Environmental Sciences, 050040, Al-Farabi ave., 71, Almaty, Kazakhstan, e-mail: Tumazhanova@atu.kz

\begin{abstract}
Citation: Aktymbayeva, B., Koshkimbayeva, U., Abisheva, Z., Tokbergenova, U., \& Tumazhanova, M. (2020). TOURISM INDUSTRY DEVELOPMENT AND GOVERNANCE: A COMPARATIVE STAGE REVIEW OF KAZAKHSTAN'S EXPERIENCE FOR THE YEARS OF INDEPENDENCE, 1991-2020. GeoJournal of Tourism and Geosites, 34(1), 69-76. https://doi.org/10.30892/gtg.34110-621
\end{abstract}

\begin{abstract}
Kazakhstan has the rich potential for tourism due to its rich culture, geographical and biological diversity, history, rugged mountains, gorgeous lakes, rivers, deserts, and has a lot of attractions and sites that satisfy the needs of domestic tourists as well as international tourists. However, the country has not yet achieved its incredible tourism potential, while tourism development in Kazakhstan began since 1990s. Therefore, the aim of this article is to examine the genesis and formation of the tourism industry in Kazakhstan and it considers how the situation in the tourism industry has regressed or progressed historically since independence. In addition, the article indicates what changes have taken place in the tourism industry in Kazakhstan over the past decade, as well as how the tourism industry has been influenced by government policy and incentive mechanisms. A systematic literature review is carried out that analyses published studies, evaluates contributions and summarises knowledge. The data for this article was collected from the National Committee on Statistics, Kazakhstan Tourism Association, National Committee on Tou rism Industry as well as the official information portal of the Republic of Kazakhstan on tourism. National regulations, programs, international and national reports have been used as a theoretical and methodological base for analysis and review. The formation of tourism industry from the moment of gaining state independence is divided into three period stages including 1990s, 2000s and 2010s. The article outlines the main problems that hinder the development of the tourism industry in Kazakhstan, and on this basis, some policy recommendations are proposed. The touri sm sector has to adopt a principal part in conserving and improving the situation in order to safeguard tourism's largest commodity, and assure the on-going success of the industry. Communities and tour operators must form a powerful association and acknowledge each other's crucial involvement. To attain the required objectives, strong collaboration among the national, provincial, and local governments, private sectors, and other concerned organizations is compulsory.
\end{abstract}

Key words: tourism industry, tourism development, international arrival, tourism growth, Kazakhstan

\section{INTRODUCTION}

Tourism is a societal, cultural, and monetary factor that involves the movement of persons to countries or sites outside their homes for individual or business/professional aims. It is multidimensional commercial activity which has great job generation capacity through its labour-intensive nature, revenue creation via tax collection generally from the hotel sectors, earnings of massive foreign exchange and prelation of cross-cultural apprehension and cooperation, business opportunities for entrepreneurs, and economic development of the country (Abishev, 2010; Abubakirova et al., 2016). Over the last few decades, global tourism has gained prominence in several economies worldwide. Tourism may also be a source of income to students, parents, retirees, and many other people by providing parttime jobs (Kuralbayev et al., 2016; Koshim et al., 2020). The function of global tourism is significant in encouraging global peace by inducing intermediation and forming a channel among cultures. Global tourism also helps destination countries at the micro level to increase the degree of family earnings by the following two means. The history of global tourism can be divided into four sta ges: Stage 1: before the beginning of the 19th century - the prehistory of tourism; Stage 2: the beginning of the XIX century - the beginning of the XX century - the emergence of specialized enterprises for the production of tourist services; Stage 3: the beginning of the XX century before the Second World War - the beginning of the formation of social tourism; Stage 4: after the Second World War - the modern stage - mass tourism, the formation of the tourism industry as an intersectoral complex for the production of goods and services for tourism (Achilov, 2017). At this stage that tourism acquires a truly massive character, from a luxury item it becomes a need for the majority of the population of highly developed industrial countries (Kuralbayev and Ydyrys, 2016; Chlachula, 2019).

To a certain extent, this was facilitated by a reduction in working hours, and, accordingly, an increase in free time. A powerful leisure industry is being formed with its own institutions, product, and production cycle, methods of organization and production man agement. 
The historical prerequisites for tourism in Kazakhstan are the formation and development of the Great Silk Road, the beginning of the formation of which dates back to the third millennium BC. This system of caravan roads, which in ancient times and in the Middle Ages crossed Eurasia from the Mediterranean to China, served as the sources of the emergence and development of trade and cultural ties between peoples, states, regions located in the zone of Great Silk Road (Kuralbayev and Abishev, 2017; Koshim et al., 2019). The largest shopping centers were built, where travelers from different countries stayed. The cities had trade buildings and caravanserais. Accommodation of all traveling people in yurts became simply impossible, inns began to appear, and often the most necessary services were offered including accommodation, food, water. To organize overnight stays for caravan participants along trade routes, special accommodation points were created including caravanserais, which had premises for people and pens for camels and horses. All this was surrounded by a fortress wall, which protects from natural elements, as well as from robbers.

Information about the territory of Kazakhstan before the beginning of the 18th century is scarce. The information came by chance mainly from Russian merchants and ambassadors. Peter First organized expeditions to the western part of Central Asia. In the first half of the 19th century, some of the outskirts of Turkestan began to be visited by scientists -travelers. However, the central part of Central Asia remained practically unknown, both in terms of geographical characteristics and economic opportunities. With the accession of Kazakhstan to Russia, an active study of its vast territory began. At this time, the borders of Russia were already in contact with the Central Asian khanates. Central Asia was annexed to Russia in the 19th century. In 60-70s scientific expeditions organized by the Russian Geographical Society and the Society of Natural Science moved to Kazakhstan (Mukhambetov et al., 2014; Kos him et al., 2019).

During the period when Kazakhstan was part of the USSR, tourism as a sector of the economy was not considered at all. Tourist s were made only for the purpose of recovery, recreation and excursions (Tiberghien and Garkavenko, 2013). Domestic tourism significantly prevailed over international tourism, since the difficulty of obtaining visas and closed borders significantly complicated its development. At that time, the main tourist areas of the USSR were the historical centers of Russia and Central Asia, then the Crimea and the Baltic states. In the same period, all the most valuable things that Kazakhstan had (a large territory with a wide range of natural and recreational resources, cultural wealth and historical heritage) remained in the shadows, unknown, the country's attractions were practically not advertised, which entailed a lack of demand and tourist interest (Ziyadin et al., 2019). Tourism in Kazakhstan during the Soviet period was one of the elements of the system of cultural and educational work that performed an ideological function and, despite its dominant role, was financed on a leftover basis, and also had no significant economic impact. The aim of this article is to examine the genesis and formation of the tourism industry in Kazakhstan and it considers how the situation in the tourism industry has regressed or progressed historically since independence. In addition, the article indicates what changes have taken place in the tourism industry in Kazakhstan over the past decade, as well as how the tourism industry has been influenced by government policy and incentive mechanisms.

\section{METHODOLOGY}

There are three general kinds of literature reviews. The most common is theoretical backgroundl: this is the section of a journal article that gives the theoretical foundations and context of the research question, and helps to bring the research question into focus. Within an article, this section is most commonly labeled literature review, theoretical background, or something similar. Second is the literature review as a chapter of a graduate thesis. Is is designated as thesis literature review. The third kind is stand-alone literature review, a journal-length article whose sole purpose is to review the literature in a field, without any primary data (that is, new or original) collected or analyzed.

At most, results from the reviewed studies might be analyzed as the data for the literature review; however, a stand-alone literature review article does not collect or analyze any primary data. When a stand-alone literature review is conducted using a systematic, rigorous standard, it is called a systematic literature review. A systematic literature review is a straightforward methodology often applied in the social sciences and this study investigates and presents surf tourism research normatively and quantitatively. While this type of documentary analysis may satisfy the natural curiosity of those in the discipline, it is particularly useful to future research, graduate students, and faculty whereby the knowledge of research productivity facilitates an understanding of scholarly output. Although a key feature of the systematic review is the aim for comprehensive coverage of a field of study, it is a primary research activity in its own right.

Fundamentally, a systematic review covers a wide-ranging search for relevant studies on a specific topic, and those identified are then evaluated according to a pre-determined explicit method. In contrast to single studies taken in isolation, the systematic and statistical summary of a determined body of research results in a research synthesis, a methodology which is highly progressive. In the context of tourism, the key to systematic review is that the criteria for the inclusion or exclusion of studies in the review is explicit from the outset, and while others may not agree with the inclusions, the criteria for such inclusions, and thus the scope of the review, are clearly delimited. A systematic literature review is a means of evaluating and interpreting all available research relevant to a particular research question or topic area or phenomenon of interest. The research papers summarised in the review are referred to as primary studies, while the re view itself is a secondary study. The accumulation of evidence through secondary studies can be very valuable in offering new insights or in identifying where an issue might be clarified by additional primary studies. Performing a systematic review involves several discrete activities, which can be grouped into three main phases: planning; conducting the review; and reporting the review. Systematic literature reviews are primarily concerned with the problem of aggregating empirical evidence which may have been obtained using a variety of techniques, and in potentially widely differing contexts. Systematic literature reviews can and are conducted with varying standards of rigor, ranging from little more than an annotated bibliography to scientifically rigorous syntheses of a body of primary research.

\section{STAGES IN TOURISM DEVELOPMENT IN KAZAKHSTAN OVER THE YEARS OF INDEPENDENCE}

With the beginning of a new page in the development of the country, with the adoption on December 16, 1990 of the Declaration of State Sovereignty, Kazakhstan (at that time still the Kazakh SSR) took the first step towards the development of the tourism industry. In August 1991, the Ministry of Tourism was established. With the acquisition of independence in the Republic of Kazakhstan, the foundation was laid for the regulation of tourist activities and the revival of the historical and cultural heritage of the people. The development of tourism in the country began to be regulated by: the Law of the Republic of Kazakhstan "On Tourism" dated July 3, 1992 No. 1508-XII; by decrees of the President of the Republic of Kazakhstan: "On the implementation of the Tashkent Declaration of the heads of the Turkic-speaking states, the project of UNESCO and the World Tourism Organization for the development of tourism infrastructure on the Great Silk Road in the Republic of Kazakhstan" dated April 30, 1997, No. 3476; "On the State Program of the Republic of Kazakhstan on Revival of the Historical Centers of the Silk Road, Preservation and Continuous Development of the Cultural Heritage of the Turkic-speaking States, Creation of Tourism Infrastructure" dated February 27, 1998, No. 3859.

The adoption of these documents had a positive impact on the development of the Kazakhstani tourism market (Zaman et al., 2016). According to Kazakhstani National Statistics (KNS, 2020), the direct contribution of travel and tourism is USD 3.14 bn (1.70\% of GDP) 
and it is predicted to increase by $2.1 \%$ (USD 4.5 bn) in 2021 and expected to grow by $3.1 \%$ to USD 7.6 bns of GDP by 2030 (Table 1 ). During the independence, the total tourist arrivals increased from 202,000 in 1996 to $9.58 \mathrm{~m}$ in 2019 (Table 1). The main source of visitors is traditionally the ex-soviet countries, accounting for $91.7 \%$ of arrivals and $70.6 \%$ of spending. Visitors from other countries made up $8.3 \%$ of the total visitors but $29.4 \%$ of the spending. Domestic tourism is also on the rise, with $4.7 \mathrm{~m}$ trips in 2019 , up $7.0 \%$ over 2018. Overnight trips accounted for $94.0 \%$ of domestic arrivals in 2019. The total budget for tourism in 2018 was 1.4 bn, rising to $1.6 \mathrm{bn}$ in 2019. The increased funding is intended to improve the infrastructure of tourist destinations, investment attractiveness, and holding international and domestic events to attract tourists. The direct contribution of travel and tourism in 2019 was $3.2 \%$ of total employment, predicted to increase by $4.5 \%$ in 2021 and in 2030 increase by $5.5 \%$ of total employment. Leisure tourism has increased by $2.5 \%$ and is the largest sector of the tourism industry in Central Asia. Leisure travel generally consists of taking a vacation from work or everyday life. During vacation, the traveler typically aims to relax, experience new cultures and locations, and broaden their mindset and more, depending on the type of travel chosen. National leisure tourism spending in Kazakhstan reached USD 1.8 bns in 2019 (KNS, 2020).

Table 1. Development of the tourism sector in Kazakhstan

\begin{tabular}{|c|c|c|c|c|}
\hline Year & Number of tourists & Receipts, USD & Contrubution to GDP, $\%$ & Receipts per tourist, USD \\
\hline 1996 & 202,000 & $258.00 \mathrm{~m}$ & $1.20 \%$ & 1.277 \\
\hline 1997 & 284,000 & $350.00 \mathrm{~m}$ & $1.60 \%$ & 1.232 \\
\hline 1998 & 257,000 & $454.00 \mathrm{~m}$ & $2.10 \%$ & 1.767 \\
\hline 1999 & 394,000 & $394.00 \mathrm{~m}$ & $2.30 \%$ & 1.000 \\
\hline 2000 & $1.68 \mathrm{~m}$ & $403.00 \mathrm{~m}$ & $2.20 \%$ & 239 \\
\hline 2001 & $2.69 \mathrm{~m}$ & $502.00 \mathrm{~m}$ & $2.30 \%$ & 186 \\
\hline 2002 & $3.68 \mathrm{~m}$ & $680.00 \mathrm{~m}$ & $2.80 \%$ & 185 \\
\hline 2003 & $3.24 \mathrm{~m}$ & $638.00 \mathrm{~m}$ & $2.10 \%$ & 197 \\
\hline 2004 & $4.29 \mathrm{~m}$ & $803.00 \mathrm{~m}$ & $1.90 \%$ & 187 \\
\hline 2005 & $4.37 \mathrm{~m}$ & $801.00 \mathrm{~m}$ & $1.40 \%$ & 184 \\
\hline 2006 & $4.71 \mathrm{~m}$ & $973.00 \mathrm{~m}$ & $1.20 \%$ & 207 \\
\hline 2007 & $5.31 \mathrm{~m}$ & $1.21 \mathrm{bn}$ & $1.20 \%$ & 229 \\
\hline 2008 & $4.12 \mathrm{~m}$ & $1.26 \mathrm{bn}$ & $0.94 \%$ & 305 \\
\hline 2009 & $3.77 \mathrm{~m}$ & $1.19 \mathrm{bn}$ & $1.00 \%$ & 314 \\
\hline 2010 & $4.10 \mathrm{~m}$ & $1.24 \mathrm{bn}$ & $0.83 \%$ & 302 \\
\hline 2011 & $5.69 \mathrm{~m}$ & $1.52 \mathrm{bn}$ & $0.79 \%$ & 268 \\
\hline 2012 & $6.16 \mathrm{~m}$ & $2.15 \mathrm{bn}$ & $1.00 \%$ & 350 \\
\hline 2013 & $6.84 \mathrm{~m}$ & $2.37 \mathrm{bn}$ & $1.00 \%$ & 346 \\
\hline 2014 & $6.33 \mathrm{~m}$ & $2.24 \mathrm{bn}$ & $1.00 \%$ & 354 \\
\hline 2015 & $6.43 \mathrm{~m}$ & $1.83 \mathrm{bn}$ & $0.99 \%$ & 285 \\
\hline 2016 & $6.51 \mathrm{~m}$ & $2.04 \mathrm{bn}$ & $1.50 \%$ & 313 \\
\hline 2017 & $7.70 \mathrm{~m}$ & $2.36 \mathrm{bn}$ & $1.40 \%$ & 306 \\
\hline 2018 & $8.79 \mathrm{~m}$ & $2.65 \mathrm{bn}$ & $1.50 \%$ & 302 \\
\hline 2019 & $9.58 \mathrm{~m}$ & 3.14 bn & $1.70 \%$ & 358 \\
\hline
\end{tabular}

One of the key factors in the development of the tourism industry in the country after gaining independence was the entry of the Republic of Kazakhstan into the UN World Tourism Organization as a Full Member, as well as the conclusion of the first international agreements on cooperation in the tourism field. At the same time, it is important to note that in most cases the initiators of the signing of these agreements were the governments of foreign states, which call the republic a promising partner and see it as rich in tourism potential. Tourism in many aspects has become a leader in the formation of market relations in Kazakhstan (Bozhko, 2017; Kairova et al., 2018). As international and domestic experience shows, tourism in a short time can become one of the most profitable spheres of the economy. World experience also shows that the market economy is the most favorable economic environment for the development of tourist activities. This means that the process of development of tourism activities is inseparably linked with the expansion of the scope of market relations.

To identify the most promising direction for the development of the tourism industry in Kazakhstan, the formation of tourism industry over the past decade should be considered and analyzed and to be more precise, from the moment of gaining state independence. This analysis will provide a clear picture of the trends in the current development of the industry, as well as the changes that have already taken place. Therefore, it makes sense to consider each stage separately. After the adoption of the Constitutional Law on the State Independence of the Republic of Kazakhstan on December 16, 1991, the development of the tourism industry in the country can be divided into three time periods indicated in the following Table 2.

Table 2. A stage review of tourism industry development and governance

\begin{tabular}{|c|c|c|c|c|}
\hline & Economic aspect & $\begin{array}{l}\text { Law aspect } \\
\end{array}$ & Political aspect & Social aspect \\
\hline 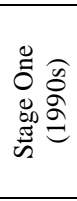 & $\begin{array}{l}\text { The process of disclosure and } \\
\text { privatization in tourism has begun. } \\
\text { Growth of indicators for incoming and } \\
\text { outcoming tourism, the opening of } \\
\text { new travel companies, an increase in } \\
\text { the profitability of the industry. }\end{array}$ & $\begin{array}{l}\text { Resolution of the Cabinet of Ministers of the } \\
\text { Republic of Kazakhstan "On the Development of } \\
\text { Tourism and Sports in the Republic of Kazakhstan", } \\
\text { the Law of the Republic of Kazakhstan "On } \\
\text { Tourism", "Regulation on Licensing, Certification } \\
\text { of Tourist and Sports Activities". }\end{array}$ & $\begin{array}{l}\text { Opening of borders for } \\
\text { incoming and } \\
\text { outcoming visa } \\
\text { formalities, influx of } \\
\text { foreign investors. }\end{array}$ & $\begin{array}{l}\text { Participation of } \\
\text { travel agencies in } \\
\text { sponsorship. }\end{array}$ \\
\hline 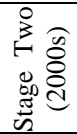 & $\begin{array}{l}\text { Stagnation of indicators for incoming } \\
\text { tourism, decline in indicators of domestic } \\
\text { tourism, an increase in the number of } \\
\text { firms specializing in shop tourism. }\end{array}$ & $\begin{array}{l}\text { "National Program for the Development of Tourism } \\
\text { in the Republic of Kazakhstan" and the licensing } \\
\text { system for tourism activities has been revised. }\end{array}$ & $\begin{array}{l}\text { The decline in } \\
\text { business activity of } \\
\text { foreign citizens. }\end{array}$ & $\begin{array}{l}\text { Participation of a } \\
\text { number of } \\
\text { companies in } \\
\text { sponsorship events. }\end{array}$ \\
\hline 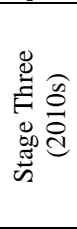 & $\begin{array}{l}\text { Changes in the structure of tourism } \\
\text { types, decline in incoming tourism } \\
\text { indicators, increased competition, use } \\
\text { of marketing and advertising means. }\end{array}$ & $\begin{array}{l}\text { Rules for licensing tourism activities in the } \\
\text { Republic of Kazakhstan, Resolution of the } \\
\text { Government of the Republic of Kazakhstan dated } \\
\text { December 29, } 200 \text { No. } 1947 \text { "On priority measures } \\
\text { for the development of the tourism industry", Law } \\
\text { of the Republic of Kazakhstan No. 211-II "On } \\
\text { tourism activities in the Republic of Kazakhstan". }\end{array}$ & $\begin{array}{l}\text { Further simplification } \\
\text { of visa formalities, } \\
\text { integration processes } \\
\text { in tourism activities. }\end{array}$ & $\begin{array}{l}\text { Benefits for } \\
\text { pensioners, large } \\
\text { families are used, } \\
\text { tourist monuments } \\
\text { are being restored. }\end{array}$ \\
\hline
\end{tabular}




\section{STAGE ONE (1990s)}

The beginning of the independence of the Republic of Kazakhstan is characterized by the rapid development of international tourism. In connection with the emergence of the possibility of free travel abroad, during this period, mainly outbound tourism is developing, the share of which largely exceeds incoming and out going tourism (Macerinskiene and Sakhanova, 2011; Tleubayeva, 2018).

The first stage became a turning point in the development of tourism in Kazakhstan, the transition to a market economy contributed to a change in the structure of the tourism industry, an increase in the number of travel agencies, the emergence of new laws, norms and rules that create conditions for the development of private entrepreneurship in tourism. This stage should be given special attention, since it is characterized by an extensive growth in tourism indicators in the republic. To improve the quality and further development of the tourism industry, the Cabinet of Ministers of the Republic of Kazakhstan approved the "Regulations on licensing, certification of tourism and sports activities", which decided: "State, public and commercial organizations engaged in tourism activities must obtain licenses from the Ministry of Tourism, Physical culture and sports of the Republic of Kazakhstan". It should be noted that the introduction of this licensing made it possible to regulate tourism activities in the country, and, as a result, it was possible to observe an improvement in the quality of service for tourists both in the country and abroad. It is also impossible not to note the strictly conducted inspection and supervision of tourist services, which allowed the state to control the quality of the services offered and, as a result, to increase the responsibility of tourist enter prises for the reception, accommodation and customer service. Attaching great importance to the role of tourism in the development of international cooperation and the formation of a strong economy, the Cabinet of Ministers of the Republic of Kazakhstan adopted a "Resolution on the Development of Tourism and Sports", the purpose of which was "... to free enterprises and organizations that channel profits from production activities to the development of tourism, physical culture and sports, reconstruction, construction of tourist and sports facilities, as well as those carrying out their construction, from the payment of taxes on profits in the part that is aimed at these purposes; to exempt tourist and sports facilities from value added taxes received from services of a tourist and sports nature" (Varavin and Kozlova, 2018; Thapa, 2019).

At the first stage, there was a significant increase in the number of travel companies. If until 1991 only 3 organizations were engaged in tourism in Kazakhstan ("Kazakh Republican Council for Tourism and Excursions", "Intourist", BMMT "Sputnik"), then in 1994, 589 tourist organizations were registered in Kazakhstan. Outbound tourist flows were focused on Poland, China (interest in shopping tours prevailed) and Bulgaria (for recreation). The countries generating tourist flows to Kazakhstan during this period were Great Britain, Germany, China and the USA. The share of tourism in GDP during this period was in $1991-0.03 \%$, in $1992-0.09 \%$, in $1993-0.06 \%$, in $1994-0.08 \%$. The volume of outbound tourism in the period from 1992-1994 has grown three times. If in 1992 there were 233990 tourists who left the republic, then in 1994, respectively, 700492 tourists. The number of tourists visiting the republic during this period has doubled, since, 236,044 foreign tourists were received in Kazakhstan in 1992, and, 450,718 tourists in 1994. The reforms carried out, mainly the simplification of visa formalities, the opening of the borders of Kazakhstan for foreign investors, contributed to the rapid growth of, first of all, international tourism. Especially fast rates are typical for the indicators of sending citizens of Kazakhstan abroad. Much attention was paid to business trips of foreign tourists to Kazakhstan, which is associated with an increase in investment activity in the republic.

\section{STAGE TWO (2000s)}

The second stage of transformation in tourism took place in the context of stabilization at the macro level mainly becase stable commodity, oil and gas prices on international markets (Karatayev et al., 2016; Koshim et al., 2018; Aktymbayeva et al., 2020). The country is rich in energy resources and in better economic and energy position compared to other former Soviet Union countries (Karatayev and Hall, 2020). It should be noted that international tourism in the Republic of Kazakhstan until the 90s existed as one of the most ideological spheres of activity. This stage is characterized by stagnation in inbound tourism indicators, as well as a decline in outbound tourism indicators. In the article "Formation of the tourism industry in the Republic of Kazakhstan" the author highlights the following factors, which, in his opinion, predetermined the very extensive growth of inbound tourism indicators in the country: simplification of visa formalities, removal of restrictions on the exit of citizens of Kazakhstan; accelerating the process of processing travel documents; the emergence and increase of the social stratum of the population, which has the financial capabilities to travel abroad; reorie ntation of trips of citizens of Kazakhstan from the domestic tourist market and the market of the CIS countries to the foreign market due to the rise in prices for vouchers to local resorts, growth in transport tariffs; use of foreign travel to solve material and everyday problems, replenishment of the Kazakhstani market of consumer goods (Esenov et al., 2018; Allayarov et al., 2018). At this stage, a number of international agreements on cooperation in the field of tourism were concluded: between the Republic of Kazakhstan and the Republic of Iran; between the Republic of Kazakhstan and the Republic of Pakistan; The Ministry of Tourism, Culture and Sports of the Republic of Kazakhstan and the Ministry of Youth, Sports and Tourism of the Republic of Moldova; Ashgabat agreement on cooperation in the field of tourism with the CIS countries; between the Government of the Republic of Kazakhstan and the Government of the Republic of Uzbekistan on deepening cooperation in the field of culture, healthcare, science, education, tourism and sports; between the Ministry of Youth, Tourism and Sports of the Republic of Kazakhstan and the State Committee of the Kyrgyz Republic on Tourism and Sports; between the Ministry of Youth Affairs, Tourism and Sports of the Republic of Kazakhstan and the Ministry of Industry and Trade of the Hungarian Republic.

During this period, the following international agreements on cooperation in the field of tourism were concluded: between the Ministry of Youth, Tourism and Sports of the Republic of Kazakhstan and the State Committee of the Kyrgyz Republic on Tourism and Sports; between the Ministry of Youth, Tourism and Sports of the Republic of Kazakhstan and the Ministry of the Arab Republic of Egypt; between the Government of the Republic of Kazakhstan and the Government of the State of Israel; between the Government of the Republic of Kazakhstan and the Government of Georgia; between the Ministry of Education and Culture of the Republic of Kazakhstan and the State Agency of the Kyrgyz Republic under the Government of the Kyrgyz Republic on cooperation in the field of tourism, physical culture and sports; between the Government of the Republic of Kazakhstan and the Government of Turkmenistan; between the Government of the Republic of Kazakhstan, the Government of the Kyrgyz Republic and the Government of the Republic of Uzbekistan on cooperation in the field of tourism. At the end of the 90 s of the last centuries, a number of separate events were held to form the tourism industry of the republic. On February 27, 1998, the Decree of the President of the Republic of Kazakhstan No 3850 "On the State Program of the Republic of Kazakhstan" Revival of historical centers of the Silk Road, preservation and successive development of the culture of the Turkic-speaking states, development of tourism infrastructure was issued, the National Company Silk Road - Kazakhstan was created. Also, in 1998, travel companies of Kazakhstan presented the republic at the International Tourism Exchange in Berlin. In January 1999, the state management of tourism was transferred to the Ministry of Transport, Communications and Tourism of the Republic of Kazakhstan. In September 1999, the Ministry of Transport, Communications and Tourism, together with the Ministry of Foreign Affairs of the Republic of Kazakhstan, adopted an interdepartmental Program of Activities of the Embassies of the Republic of Kazakhstan on the development of relations in the field of tourism, aimed at attracting investments in the tourism sector, increasing the tourist flow, as well as protecting interests and rights Kazakh 
tourists abroad (Baiburiev et al., 2018; Akbar et al., 2020). In the period from 1999 to 2000, the following international agreements on cooperation in the field of tourism were concluded: between the Ministry of Education, Culture and Health of the Republic of Kazakhstan and the State Administration for Tourism; between the Government of the Republic of Kazakhstan and the Government of the Turkish Republic; between the Government of the Republic of Kazakhstan and the Government of the Republic of Bulgaria on cooperation in the field of tourism. The state concept of tourism development, including the issues of improving its infrastructure, significantly differed from those adopted throughout the world. Therefore, at this stage, the changes were difficult and inadequate.

\section{STAGE THREE (2010s)}

The third stage began in 2000 and continues to this day. In general, it was this stage and the current policy in the field of tourism that gave impetus to progressive changes. A feature of this stage is the reform of the legal framework in the field of tourism and the development of a new concept of tourism development. State support for the first time is manifested in the financial support of the indus try (Dikareva and Koroleva, 2017; Mamutova, 2020). At this stage, the activation of tourism activities at the state level begins. The Resolution of the Government of the Republic of Kazakhstan dated December 29, 2000 No 1947 "On priority measures for the development of the tourism industry" was adopted. This document focuses on such issues as the simplification of visa formalities when entering the Republic of Kazakhstan, the organization by the Agency of the Republic of Kazakhstan for Tourism and Sports of international exhibitions and fairs, the use of incentives for tourists on tariffs for transport services, the formation of a loan program for tourist organizations for $2001-2005$ years. Almost the first steps outlined by this decree were taken in 2002, and from 25 to 27 April in the city of Almaty the second Kazakhstan International Tourism Fair "Tourism and Travel" - KITF was organized, in which about 80 tourist organizations took part. The outlined processes are associated with the international tourism market, the intensification of the activities of all structures of the tourism sector was noted, in particular, participation in the International Tourism Exchanges in the cities of Berlin and London, the Moscow, Tashkent International Exhibitions and the International Tourism Forum in 2001 (Artykbaev et al., 2019; Artykbaev et al., 2020).

In 2000-2003, an action plan for the formation of the tourist image of Kazakhstan was carried out. As part of the implementation of this plan, with the participation of the Agency of the Republic of Kazakhstan for Tourism and Sports, the Spanish television company "CROMA Television" organized and filmed a documentary video about the history, culture and customs of the country. The documentary film consists of 4 parts characterizing the picturesque places of the republic, infrastructure, historical sites, folk art, traditions and customs. The film was broadcast on the European Plus channel. The premiere screening of the documentary film "Kazakhstan: a journey into the heart of Eurasia" was held at the Embassy of the Republic of Kazakhstan in the Kingdom of Spain with the participation of the President of the Republic of Kazakhstan N.A. Nazarbayev. In addition, CROMA Television, commissioned by the Agency of the Republic of Kazakhstan for Tourism and Sports, produced an advertising video about the tourism opportunities in Kazakhstan.

In the tourist activity of Kazakhstan, there has been a tendency of integration into the world tourist market. Integration processes on the section of the Great Silk Road are especially strengthening in terms of tourism development. For this reason, the Agency of the Republic of Kazakhstan for Tourism and Sports has developed the State Program "Revival of the Historical Centers of the Silk Road, Preservation and Continuous Development of the Cultural Heritage of the Turkic-Speaking States, Creation of Tourism Infrastructure". Based on this program, in April 2002 in the city of Turkestan, a regional seminar was organized on the theme "Development of tourism on the Kazakh section of the Great Silk Road" (Panzabekova, 2018; Movkebayeva et al., 2020). At the seminar, an assessment was made of the state of development of this tourist complex. Among the positive aspects, one can note such as the restoration of cultural and historical sites, the construction of a hotel and a guest house, the reconstruction and construction of roads, the development of new routes by such tour operators as OJSC "Akmola-tourist", as well as the search for investors and the development of investment projects, part of which were submitted for consideration during the investment summit "Eurasia - 2000".

At the same time, negative aspects were also noted, among which the following can be highlighted: the entertainment infrastru cture is not fully provided, the difficulty of obtaining a visa and the high cost of visas. On June 13, 2001, the country adopted the Law of the Republic of Kazakhstan No. 211-II "On tourist activities in the Republic of Kazakhstan", which defines the economic, social, organizational foundations of tourist activities in the country. This resolution clearly defines the category and con ceptual apparatus in the field of tourism, discloses the main terms and concepts used in the field of tourism, delimits the areas of activity of state and local authorities, and defines the principles and features of licensing of tourism activities in Kazakhstan. The resolution also addresses issues related to contractual relations, professional training of specialists in this industry, the rights and obligations of touris ts, insurance in the implementation of tourist activities. At the third stage of tourism development, the licensing system for tourism activities in the Republic of Kazakhstan was also revised, since on September 14, 2001, the Rules for Licensing Tourism Activities in the Republic of Ka zakhstan were adopted, according to this provision, the licensing system was more stringent and it became much more difficult for a travel company to obtain a license. By the Decree of the Government of the Republic of Kazakhstan dated December 29, 2002 No. 1445, the Program for the Development of the Tourism Industry for 2003-2005 was approved. The developed program presented a specific action plan aimed at state regulation and support of tourist activities. All the issues under consideration can be grouped as follows: improving the quality of tourist services through the development of standards in the field of tourism; development of tourism infrastructure with the attraction of foreign investment; professional development of personnel for tourism workers; improving the medical system and ensuring safety in tourism; improvement of statistics and accounting of indicators of the tourism industry; ensuring a positive image through active participation in international fairs, exhibitions and stock exchanges, creating booklets and brochures about the tourist resources of Kazakhstan; ensuring environmental protection and balance of ecology (Mussina, 2018; Tiberghien, 2019).

Another important impetus for the development of the tourism industry was the recognition of the tourism industry as one of the priority sectors of the economy among seven cluster initiatives. As part of the development of the tourism cluster in the republic, priority directions for the development of tourism were identified, such as business, environmental, cultural and educational, as well as extreme types of tourism. Based on this, by the Resolution of the Government of the Republic of Kazakhstan dated June 25, 2005 No. 633 "On approval of plans for the creation and development of pilot clusters in priority sectors of the economy", a plan was approved for the creation and development of a pilot cluster "Tourism" in the city of Almaty and the Almaty region. Taking into account the importance of creating a tourism cluster, in 2005 the Government of the republic allocated funds to conduct marketing research of the tourism potential of the regions of Kazakhstan in order to determine the further development strategy of the tourism industry. To carry out these studies, the company "IPK International" was involved, which occupies a leading position in the development of strategies and the promotion of tourism products on the world market of tourism services.

At the last stage, it is possible to differentiate the development of tourism at the enterprise level, depending on its dimen sion. Large enterprises that use the differentiation strategy as their basis have a fairly wide range of services offered, diverse travel geography and offer 
different countries and regions, thereby insuring themselves against possible failures and economic risks. The results of the polls conducted by the author among large tour operators showed that the main problem in their activities is obtaining entry visas to a number of states, in particular to America, France and other countries of the Schengen agreement. The main problem of small travel companies is the lack and limited financial resources, which negatively affects their activities. In general, the analysis of tourism activities in Kazakhstan made it possible to systematize and present the specifics and features of tourism development at each stage.

Based on the above analysis, we can conclude that the most active in terms of reforming the legislation on tourism in Kazakhstan were the first and third stages, and in economic terms, the greatest rise in indicators is observed in the second period. If we consider the issues of the political aspect, then we can state the fact that the decisive were the first and third periods, which opened up opportunities for the development of international tourism. If initially social factors were not so important for tourist activity, then later we observe that they began to be given some attention (Rakhmatullayeva et al., 2015; Aliyeva et al., 2019). The development of the economy of Kaza khstan, the implementation of a set of measures for the industrial and innovative development of the country contribute to the active attraction of foreign capital. Therefore, there are all the prerequisites for attracting foreign and domestic investment in the development of the tourism industry, the formation of a high level of tourism management in order to ensure clear coordination of actions of the central and regional levels of government, to promote the development of private initiatives; creation of an information space for the industry, development of an effective system for promoting Kazakh tourism products to foreign and domestic markets; adoption of the necessary regulatory legal acts on investment and taxation. These are the main directions of cluster tourism development, planned for implementation within the framework of the developed regional master plans. Thus, over the years of state independence of Kazakhstan, a number of important events were held to form the national tourism industry of the republic, 22 international agreements were concluded in the field of cooperation in the field of tourism, which have a huge potential for social efficiency.

\section{PROBLEMS FOR FURTHER DEVELOPMENT}

In May 2019, the Government approved The Programme for the Development of the Tourism Industry for 2019-25. The Programme is designed to improve the availability and quality of tourist services and products, as well as the quality of life of the population of the country by developing places of tourist interest and upskilling human resources for the sector. It also focu ses on the growth of external and internal tourist flows, increasing investment in the tourism industry by creating a favourable tourist climate, and promotion of the tourist potential of Kazakhstan in both domestic and international markets. Kazakh Tourism JCS used the Programme to guide its marketing and promotion and to attract investment in tourism. Although Kazakhstan has a favourable geopolitical position, with significant natural and recreational resources and world cultural and historical heritage sites, the country is an emerging tourism destination and is not yet competitive against popular countries for tourism and travel. The government recognises that the quality of tourist infrastructure, openness of bilateral service agreements, complexity of the visa regime, and low quality of roads are areas for further improvement. The 2019-25 Programme is focusing on resolving these issues and aligning performance with international standards. This work is developed in the context of wider legislation designed to transform the economy of Kazakhstan and includes significant institutional and economic reforms as well as sector development and specialisation. To achieve these targets, the institutional framework has been strengthened, national and local executive bodies formed, working alongside the National Tourism Organisation, Kazakh Tourism JSC, and additional co-ordination measures developed to deal with the cross-cutting nature of tourism, which is estimated to link 30 different sectors in Kazakhstan. Low levels of investment inhibit the industry's development and restrict potential growth. In 2017, the country attracted KZT 295.7 billion in fixed capital investment in tourism, 36.6\% more than in 2016. In 2018, total investment increased by 65\% compared to 2017 and amounted to KZT 447.3. However, many major investment projects are still not able to be implemented due to a lack of state support mechanisms and a lack of long-term and affordable finance for the industry.

In order to attract investors to the tourism industry, the government is carrying out the following work: ensuring the necessary engineering and transport infrastructure are brought to investment projects; creating a preferential regime for investors, in cluding the provision of in-kind grants and exemptions from corporate income tax, land and property tax. The minimum threshold has been reduced from KZT 4.7 billion to KZT 4.7 million for tourism projects; a programme has been launched to provide SMEs with financial re sources for investment projects in the tourism industry at a preferential rate of $6 \%$. The core priority of the Ministry of Culture and Sport and the government is to increase tourist flows and attract a larger share of the international market. The number of tourism related businesses has been increasing by $10 \%$ to $15 \%$ each year, but regional tourism development is unco-ordinated. For example, formal regional strategies are not in place to enable the development of the most promising destinations and products.

The Programme for the Development of the Tourism Industry for 2019-25, aims to position Kazakhstan as one of the 50 most attractive countries for travel in the world by 2025. This will be achieved by reference to the following indicators: increase the contribution of tourism to the country's GDP from 5.7\% to $8 \%$; increase the number of people employed in the tourism industry from 440000 to 650000 ; increase the number of overseas tourists from the 830000 to 3 million; increase the number of domestic tourists from 5 million to 8 million; increase the volume of tourism services rendered from EUR 256 million to EUR 630 million; increase tourism investment from EUR 700 million to EUR 1.4 billion. The implementation cost of the Programme is KZT 2.2 trillion, mor e than half of which is financed by the Government, while the remainder comes from the private sector. Kazakhstan is an emerging tourist destination with limited tourism infrastructure, weak product and services offers, and does not have a high image in global tourism markets. Priority measures, such as visa reforms, air access and high quality accommodation, are a critical part of the current tourism plan. Research has indicated that Kazakhstan has over 100 potential 'tourism magnets' and 'points of tourism growth'. Due to limited resources, and the need for significant investment in each, these have been prioritised at both national and regional levels. This has resulted in the development of a comprehensive map of potential sites and opportunities by the Committee of the Tourism Industry. Various selection criteria underpinned the selection process for these sites, including uniqueness, historical and cultural significance, and availability of accommodation. The development of the accommodation and hospitality sector is a significant challenge given a lack of skills, the remoteness of many providers and the difficulty in tracking the quantity of stock at national or regional levels using official statistics. A framework for the operation of the sector is currently being developed including a National Hostels Standard, which is being implemented on a voluntary basis. In 2019, the government created a specialised educational institution - The International University of Tourism and Hospitality - as a model of international and national best practice in the training of tourism personnel. The University aims to improve the training system and increase the competence of personnel in the tourism industry to meet international standar ds.

Kazakhstan as a tourist destination is certainly attractive for foreign tourists and the local population. Nevertheless, there are a number of constraining factors that hinder the full development of tourism in the country. These mainly include: 1) lack of information about the tourism potential of the Republic of Kazakhstan in the international market;2) lack of qualified personnel in the tourism sector 
- including some discrepancy between educational programs and labor market requirements, production needs and employers' expectations; 3) insufficient development of transport infrastructure (Kantarci, 2007; Kantarci et al., 2017; Aliyeva et al., 2020). In order to solve existing problems, as well as to further improve this industry, the head of state, N.A. Nazarbayev, the Concept for the Development of the Tourism Industry of the Republic of Kazakhstan until 2020 was developed and formed. This Concept is aimed at the sustainable development of the tourism industry through the creation and modernization of infrastructure, the formation of the image of Kazakhstan to increase its attractiveness as a tourist destination (Aktymbayeva et al., 2020).

The main reason hindering the development of the tourism product of the Republic of Kazakhstan is its lack of publicity and poor promotion in the international market. In this regard, the National Tourism Development Company will be established. The primary task of the company is to develop an image strategy, which provides for the creation of a travel brand (Akhmedenov, 2020). The formation of the image of the Republic of Kazakhstan will be implemented, firstly, by creating a specialized online platform that reflects all the country's tourist offers and provides online booking functions. Further, the promotion of tourist destinations will be carried out through mobile advertising and placement of banners on websites, as well as in popular social networks of the planet (for example, Facebook, Trip Advisor and others). Secondly, tourist offices, visit centers and information bureaus of the Republic of Kazakhstan will be opened in key markets, namely: at the first stage, one representative office will be created in Russia, one in Hong Kong and one for Western Europe. In the future, a more complete coverage of the Asian market is planned, as well as an increase in the number of representative offices in Europe. Thirdly, offsite events will be created, for example, study tours across Kazakhstan for representatives of the media and foreign specialists of the tourism industry in order to inform and familiarize themselves with the country's tourism products (Yegemberdiyeva et al., 2020).

In order to achieve high quality and competitiveness of the tourism product of Kazakhstan in the world market, it is certainly necessary to solve the problem of personnel in the country. To train employees of the tourism industry, opportunities will be created for the further development of higher, technical and vocational education, as well as trainings in the field of tourism, support for vocational training systems and schools in the tourism and hospitality industry. For this, from the second half of 2013, Nazarbayev University and the Austrian company will be involved, with which a Memorandum of Understanding has already been signed. The additional need for personnel will be replenished through retraining and advanced training in short-term training centers, including in preparation for the International Specialized Exhibition EXPO-2017 in Astana. It is the largest event, a symbol of industrialization and an open area to showcase technical and technological advances. Holding EXPO-2017 will serve to significantly promote the Republic of Kazakhstan and its capital at the international level. To ensure control over the quality of tourist services, qualification standards will be drawn up for workers in the tourist industry (guides, travel agencies and translators). The successful development of the tourism industry is due to the presence of a high quality and developed transport system that connects places of tourist interest. In order to improve transport infrastructure, first of all, the improvement of existing and construction of new airports will be carried out, as well as airports in the cities of Astana, Almaty and Chimkent will be expanded in order to increase their capacity. Then, new high-speed trains will be put into operation to open international connections with non-CIS countries and, accordingly, to minimize the duration of travel between them. Road transport development projects include the completion of the Western Europe - Western China international transport corridor, as well as roadside infrastructure. All these activities will contribute to the further development of both domestic and inbound tourism, which ultimately will lead to a significant increase in the attractiveness of the national tourism product and the integration of Kazakhstan into the system of the world tourism market.

\section{CONCLUSION}

Tourism today occupies one of the most important positions in the world economy. The systematic solution of the problems of increasing the attractiveness of the regions of the republic for tourists, the development and implementation of additional programs for the development of tourism in the regions, their timely financing and the modernization of the existing infrastructure will significantly increase the attractiveness of all tourist regions of Kazakhstan in the future. In the first part of the work, we examined how the tourism industry in the country developed before and after gaining state independence. The Republic of Kazakhstan has objective prerequisites for active integration into the world tourism market. During the years of state independence, a number of important events have been carried out in the country: joining the World Tourism Organization in 1993, introducing a certification and licensing system, which have become a kind of mechanism for controlling and monitoring the proper provision of tourist services.

During this period, 22 international agreements on cooperation in the field of tourism were concluded, which are socially effective. An important aspect, undoubtedly, is the participation of the Republic of Kazakhstan in international tourism forums and exhibitions, for example, in Berlin, London, Moscow and Tashkent, as well as holding its own annual exhibition "Tourism and Travel". It is also important that in 2005 the "Tourism" cluster was created as one of the most priority directions in the state economy, and the company "IPK International" was involved in conducting a marketing analysis of the country's tourism industry.

The main problems of tourism development in the country are highlighted: a poorly developed image of Kazakhstan, a lack of qualified personnel in this area, as well as an unsatisfactory state of the transport infrastructure. The President of the Republic of Kazakhstan developed a Concept for the Development of the Tourism Industry until 2020, which provides for ripe problems, and also suggests ways to solve them. Kazakhstan really needs well-thought-out advertising, because even the citizens themselves are often not aware of the country's potential. The policy of the state aimed at creating the image of Kazakhstan, with a serious approach and implementation of the planned measures, will give a positive result very soon. Attracting foreign professionals, such as the Austrian company WIFI International, which provides training programs and interactive training courses, will help achieve a high level of education for personnel working in the tourism sector. And the participation of the Kazakh international university Nazarbayev University will help to regulate the compliance of curricula at all levels of education.

\section{REFERENCES}

Abishev, A. (2010). Innovative reference points of the industrial policy in Kazakhstan. Economy of region, 1(3), 43-48. https://doi.org/10.17059/2010-3-3

Abubakirova, A., Syzdykova, A., Kelesbayev, D., Dandayeva, B., \& Ermankulova, R. (2016). Place of Tourism in the Economy of Kazakhstan Republic. Procedia Economics and Finance, 39, 3-6. https://doi.org/10.1016/s2212-5671(16)30232-5

Achilov, N. (2017). Development of Tourism Industry: Perspectives and Advantages for Growth as Example in Kazakhstan. Journal of Tourism \& Hospitality, 6(267), 2167-0269. https://doi.org/10.4172/2167-0269.1000267

Akbar, I., Yang, Z., Han, F., \& Kanat, G. (2020). The influence of negative political environment on sustainable tourism: A study of Aksu-Jabagly world heritage site, kazakhstan. Sustainability, 12(1), 143. https://doi.org/10.3390/su12010143

Akhmedenov, K.M. (2020). Tourist and recreational potential of the salt lakes of Western Kazakhstan. GeoJournal of Tourism and Geosites, 30, $782-787$. https://doi.org/10.30892/gtg.302sp101-505

Aktymbayeva, A., Assipova Zh., Moldagaliyeva A., Nuruly Y., \& Koshim A.(2020). Impact of small and medium-sized tourism firms on employment in Kazakhstan. GeoJournal of Tourism and Geosites, 32(4), 1238-1243. https://doi.org/10.30892/gtg.32407-563 
Aktymbayeva, A., Orazgaliyeva, A., Omarova, A., Tulaganov, A., Akhmetova, A., Tyurina, Y., \& Troyanskaya, M. (2020). The Central Asian economies of water-energy security: The future role of hydro and fuel-based systems. International Journal of Energy Economics and Policy, 11 (1), 417-425. https://doi.org/10.32479/ijeep.10267

Aliyeva, S., Chen, X., Yang, D., Samarkhanov, K., Mazbayev, O., Sekenuly, A., \& Kozhokulov, S. (2019). The Socioeconomic Impact of Tourism in East Kazakhstan Region: Assessment Approach. Sustainability, 11(17), 4805. https://doi.org/10.3390/su11174805

Aliyeva, Z., Sakypbek, M., Aktymbayeva, A., Assipova, Z., \& Saidullayev, S. (2020). Assessment of recreation carrying capacity of Ile-Alatau national park in Kazakhstan. GeoJournal of Tourism and Geosites, 29 (2), 460-471. https://doi.org/10.30892/gtg.29207-482

Allayarov, P., Embergenov, B., \& Han, S.T. (2018). Problems and Prospects of sustainable tourism in the Republic of Kazakhstan. Business and Economic Research, 8(2), 115-126. https://doi.org/10.5296/ber.v8i2.12951

Artykbaev, D., Baibolov, K., \& Rasulov, H. (2020). Stability analysis of fine soils from a road project, M32 Samara-Shymkent (Russia-Kazakhstan). International Journal of GEOMATE, 19(76), 205-212. https://doi.org/10.21660/2020.76.78503

Artykbaev, D., Rasulov, H., Baybolov, K. (2019). Influence of soil density and moisture on seismic stability of slope structures. International Journal of Engineering Research and Technology, 12(8), 1259-1262

Baiburiev, R., David, L., Abdreyeva, S., Zhakupova, A., \& Artemyev, A. (2018). Impacts of tourism activities on economy of Kazakhstan. GeoJournal of Tourism and Geosites, 22 (2), 480-488. https://doi.org/10.30892/gtg.22217-304

Bozhko, L.L. (2017). Government support for monotowns in the Republic of Kazakhstan. R-Economy. 3(1), 1-11. https://doi.org/10.15826/recon.2017.3.1.001 Chlachula, J. (2019). Geo-tourism perspectives in East Kazakhstan. Geography, Environment, Sustainability, 12(2), 29-43. https://doi.org/10.24057/2071-9388-2018-78

Dikareva, T.V., \& Koroleva, E.G. (2017). Background medical-geographical assessment of regions with high environmental tourism potential in the Republic of Kazakhstan. Arid Ecosystems, 7(3), 155-160. https://doi.org/10.1134/s2079096117030040

Esenov, M.N., Beisakhmet, A.A., Kalimbetov, E.A., \& Artemiev, A.A. (2018). Tourism Opportunities for Kazakhstan on the Great Silk Road. Journal of Geography and Environmental Management, 47(4), 181-189. https://doi.org/10.26577/jgem.2018.2.450

Kairova, S.G., Essimova, D.D., \& Malikova, F.M. (2018). Sustainable Ecological Tourism Development in the Republic of Kazakhstan: Problems and Prospects. In IOP Conference Series: Earth and Environmental Science (pp. 012014-012014). https://doi.org/10.1088/1755-1315/204/1/012014

Kantarci, K. (2007). Perceptions of foreign investors on the tourism market in central Asia including Kyrgyzstan, Kazakhstan, Uzbekistan, Turkmenistan. Tourism Management, 28(3), 820-829. https://doi.org/10.1016/j.tourman.2006.05.012

Kantarci, K., Başaran, M.A., \& Özyurt, P.M. (2017). Comparative analysis of Central Asian tourism product from point of view of Turkish travelers: A case of Kyrgyzstan, Kazakhstan, Tajikistan, Uzbekistan and Turkmenistan. Eurasian Economies in Transition, 339-357. https://doi.org/10.36880/c06.01241

Karatayev, M., \& Hall, S. (2020). Establishing and comparing energy security trends in resource-rich exporting nations (Russia and the Caspian Sea region). Resources Policy, 68, 101746. https://doi.org/10.1016/j.resourpol.2020.101746

Karatayev, M., Hall, S., Kalyuzhnova, Y., \& Clarke, M.L. (2016). Renewable energy technology uptake in Kazakhstan: Policy dri vers and barriers in a transitional economy. Renewable and Sustainable Energy Reviews, 66, 120-136. https://doi.org/10.1016/j.rser.2016.07.057

Koshim, A., Karatayev, M., Clarke, M.L., \& Nock, W. (2018). Spatial assessment of the distribution and potential of bioenergy resources in Kazakhstan. Advances in Geosciences, 45, 217-225. https://doi.org/10.5194/adgeo-45-217-2018

Koshim, A.G., Sergeyeva, A.M., Bexeitova, R.T., \& Aktymbayeva, A.S. (2020). Landscape of the Mangystau region in Kazakhstan as a geomorphotourism destination: a geographical review. GeoJournal of Tourism \& Geosites, 29(2). https://doi.org/10.30892/gtg.29201-476

Koshim, A.G., Sergeyeva, A.M., Saparov, K.T., \& Wendt, J.A. (2019). Development of scientific tourism at Baikonur Cosmodrome Kazakhstan. GeoJournal of Tourism and Geosites, 24(1), 267-279. https://doi.org/10.30892/gtg.24121-358

Kuralbayev, A., \& Abishev, N. (2017). The measuring of the spiritual tourism in regions of South Kazakhstan. Revista ESPACIOS, 38(51). https://doi.org/10.35808/ersj/699

Kuralbayev, A., \& Ydyrys, S. (2016). Some issues of improving the quality of the labor resources in the Republic of Kazakhstan. Avrasya Uluslararast Araştırmalar Dergisi, 4(9), 131-137. https://doi.org/10.33692/avrasyad.509585

Kuralbayev, A., Myrzaliev, B., \& Sevim, B. (2016). Organizational and economic problems in the management of the spiritual-Historical development of tourism in South Kazakhstan Region. International Review of Management and Marketing, 6(2). https://doi.org/10.35808/ersj/699

Macerinskiene, I., \& Sakhanova, G. (2011). National economy competitiveness of Kazakhstan Republic. Engineering Economics, 22(3). https://doi.org/10.5755/j01.ee.22.3.519

Mamutova, K. (2020). Destination Management Approach for Sustainable Tourism Development in Kazakhstan. Eurasian Journal of Economic and Business Studies, 2(56). https://doi.org/10.47703/ejebs.v2i56.15

Movkebayeva, G., Aktymbayeva, A., Tyurina, Y., Baikadamov, N., Beketova, K., Troyanskaya, M., Smagulova, S., \& Imangaliyeva, A. (2020). Energy Security and Sustainability in Eurasian Economic Union in the Terms of Economic Growth: The Case of Kazakhstan's Energy Sector up to 2040 Perspectives. International Journal of Energy Economics and Policy, 10(2), 497-503. https://doi.org/10.32479/ijeep.9073

Mukhambetov, T.I., Janguttinav, G.O., Esaidar, U.S., Myrzakulova, G.R., \& Imanbekova, B.T. (2014). The life cycle of sustainable eco-tourism: A Kazakhstan case study. WIT Transactions on Ecology and the Environment, 187, 39-49.

Mussina, K. (2018). Modern challenges of creating tourism brand of Kazakhstan. Annals of Marketing Management \& Economics, 4(2), 75-87. https://doi.org/10.22630/amme.2018.4.2.19

Panzabekova, A.Z. (2018). Diversification of tourism and economic development of Kazakhstan. R-Economy. 4(3), 82-87. https://doi.org/10.15826/recon.2018.4.3.012

Rakhmatullayeva, D.Z., Bobkov, V.N., \& Zhatkanbayev, E.B. (2015). Modeling of Social Effect of Foreign Direct Investment in The Regions of Kazakhstan. $R$-Economy. 1(2), 325-339. https://doi.org/10.17059/2015-2-23

Thapa, B. (2019). Ecotourism education and development in Kazakhstan. Journal of Hospitality \& Tourism Education, 31(2), 119-124. https://doi.org/10.1080/10963758.2018.1485499

Tiberghien, G. (2019). Managing the planning and development of authentic eco-cultural tourism in Kazakhstan. Tourism Planning \& Development, 16(5), 494-513. https://doi.org/10.1080/21568316.2018.1501733

Tiberghien, G., \& Garkavenko, V. (2013). Authenticity and eco-cultural tourism development in Kazakhstan: A country branding approach. European Journal of Tourism, Hospitality and Recreation, 4(1), 29-43. https://doi.org/10.1201/b17367-4

Tleubayeva, A. (2018). Rural tourism as one of the priority factors for sustainable development of rural territories in Kazakhstan. Journal of Environmental Management and Tourism (JEMT), 9(06 (30)), 1312-1326. https://doi.org/10.14505//jemt.v9.6(30).21

Varavin, Y., \& Kozlova, M. (2018). Assessment of «Green» Economy Development in Regions (on the Example of the Republic of Kazakhstan). Economy of region, 1(4), 1282-1297. https://doi.org/10.17059/2018-4-18

Yegemberdiyeva, K., Yushina, Y., Khen, A., Temirbayeva, R., \& Orazbekova, K. (2020). Assessment of the natural-recreational resources of the Akmola region (based on the example of the Shchuchinsk-Borovoye resort area) for the purpose of sustainable development of tourism. GeoJournal of Tourism and Geosites, 30(2), 818-826. https://doi.org/10.30892/gtg.302sp106-510

Zaman, K., Shahbaz, M., Loganathan, N., \& Raza, S.A. (2016). Tourism development, energy consumption and Environmental Kuznets Curve: Trivariate analysis in the panel of developed and developing countries. Tourism Management, 54, 275-283. https://doi.org/10.1016/j.tourman.2015.12.001

Ziyadin, S., Litvishko, O., Dubrova, M., Smagulova, G., \& Suyunchaliyeva, M. (2019). Diversification tourism in the conditions of the digitalization. International Journal of Civil Engineering and Technology, 10(2), 1055-1070. 